\title{
SOCIAL WORK IN MENTAL RETARDATION
}

\author{
Yvonne Herring \\ Social Worker, Alexander Care and Rehabilitation Centre, Maitland.
}

\section{OPSOMMING}

'n Omwenteling is vandag besig om plaas te vind binne die veld van geestesvertraagdheid. Die konsep van die totale mensbenadering wat in die psigiatrie geld, bring verrykende gevolge vir die multi-professionele span mee wat met die geestesvertraagde mens gemoeid is. Daar word van die professionele persoon verwag om genoemde mens binne die gesinsverband te behandel, terwyl daar vir sommige ouers en gemeenskappe slegs een oplossing vir hul probleem bestaan, naamlik institusionalisering van so 'n persoon.

Die verwydering van 'n geestesvertraagde uit die gesinsverband is nie noodwendig 'n oplossing vir die “probleem" nie - inteendeel, daar kan 'n verdere isolasie tussen die gesinslede plaasvind as gevolg van hul onverwerkte onuitgesproke gevoelens oor die aangeleentheid.

Wat dit betref, is die ingesteldheid van die maatskaplike werker wat oor die gespesialiseerde kennis van gesinsdinamika beskik, van primêre belang, en medebepalend t.o.v. hoe (en of) die houding van die gemeenskap sal verander.

“ owadays, the care of the mentally handicapped person at home is very much family psychiatry.'(3)

In this article the field of mental retardation will be examined focusing on the changes that have taken place in this field. In so doing an attempt will be made to indicate that because of these changes, new ideas and attitudes, the role of the social worker has emerged as a very important one.

The family system is regarded as the most important of all social systems. The social worker's training incorporates the study of human behaviour, human relationships and the functioning of social systems. Thus the social worker has an understanding of problems as they relate to and affect families and of problems as they relate to the community. In other words the social worker has a role in social problems and therefore possibly a specialised role in the field under discussion. A brief look at the existing institutions (centres, agencies, societies) for the mentally retarded, however, reveals that social workers are few and far between. For example at Alexandra Care and Rehabilitation Centre there is one social worker to 850 in-patients. This one social worker also works with numerous out-patients and participates in rendering the community service. The outpatients service at Alexandra Care and Rehabilitation Centre consists of family diagnostic interviews conditioned by the multiprofessional team. As a member of the team and equipped with a special knowledge of family dynamics and functioning, the social worker acts as liaison between the Centre and the referring body or agency. Furthermore it is the responsibility of the social worker to ensure that the information provided by the referring agency is specific to the criteria laid out by the multiprofessional team. During the diagnostic interview with the family (preferably the professional involved should also be present) the social worker's presence ensures an astute diagnosis of family functioning.

The community service is a continuation of the outpatient service described above. This service also includes the social worker acting in a consultative capacity to colleagues working in the community. An integral part of the community service is to ensure that the residents' integration with the community is enhanced. The social worker is responsible for the education of the community, which is necessary in order to facilitate boarding and occupation. The existing institutions do not appear to make sufficient provision for the profession. Why?

Perhaps the answer to this lies in the fact that the entire field of mental retardation is undergoing changes changes in attitudes, management and treatment of the mentally retarded - changes which began universally about fifteen to twenty years ago. It appears that the mental health professionals of the nineteenth century were very involved in the field of mental retardation. However, at the beginning of the twentieth century the "tragic interlude" (4, p.714) led the field of mental retardation into the darkness. The first twenty years of the twentieth century were marked by banishing the 
"dangerous" retardate into large institutions. The feebleminded were incurable and the role of the professional was that of a jailer and not that of the humane caretaker of the previous century. The appearance of the Binet Test and the introduction of psycho-analysis were largely responsible for the "tragic interlude". The Binet Test, indicating that I.Q. score was irreversible, revealed that there were vast numbers of mentally retarded people in society, and so those who could be banished, were banished. Psycho-analysis with its dynamic concepts in the treatment of psychiatric patients made treating the neurotic person far more exciting than "purposeless" activities with the mentally retarded. Consequently the field of mental retardation became a closed boring field for most professionals.

Pernaps it was the emergence of a new approach to psychiatry that once again awakened an interest in the field of mental retardation, namely that interpersonal dynamics rather than intrapersonal dynamics only are important in the field of mental illness. And perhaps the emergence of the multi-disciplinary team approach in psychiatry also contributed to the new interest of the mental health professionals in the field of their step-child, mental retardation.

It is important to note at this point that little interest was shown by the members of the multiprofessional team other than the nurse. The other disciplines in psychiatry were involving themselves in other fields for e.g. psychoneuroses leaving the nurse to carry the brunt of the service in the large institutions. Those mentally retarded patients who remained at home, were taken care of by their parents and families alone. Mental retardation was one of the few social problems where professionals were not always involved and where the parents were doing the job of caring for their children alone. What then has emerged with the new multidisciplinary team approach and what has emerged for the social worker? It was mentioned earlier that a change took place in general psychiatry where the focus was no longer on the patient alone but on the patient plus those with whom he interacts, namely his family.

Family dynamics and relationships began to be examined in the process of treatment. It is possibly then too that the mental health professionals became aware of the mentally retarded person and his immediate environment, that is the family and the community.

Subsequently a new emphasis emerged in the involvement of the family of the mentally retarded.

To illustrate the latter concept, it is necessary to examine the expectations intertwined with the processes preceding the birth of a child, the actual birth of the child and the adjustment to a newborn baby.

At the birth of a child the parents are eagerly awaiting the birth of a normal perfect baby. Having given birth to an abnormal baby, the parents in fact need to mourn the loss of their image of their perfect baby, and at the same time engage with the newborn imperfect baby. This demand on the parents to disengage with the "perfect child" of their dreams and at the same time to bond with the new baby is a stressful process and evokes conflict within themselves.

At this point it is important to stop and examine how and when the "news is broken" to the parents. All too often the parents are told that their child is not normal, without fully realising the implications of such shattering news. Either the mother or the father is told alone. In some cases certain facts are withheld from the parents and other facts are not made clear to them. The parents are left shattered and trying to understand the meaning of what has happened to them. They are left on their own to work out for themselves the best way of handling the current situation as well as to plan the future for themselves and their handicapped child. It is often the case that it is suggested to these parents to institutionalise their child in the hope that further involvement and pain will be prevented. It is often these very children who are dumped in institutions. It is my experience that parents who have institutionalised their child for these reasons have in fact subjected themselves to more emotional discomfort - the original problems remain unresolved and possibly increase in spite of the "well-meaning" advice of the professional. It therefore seems that in the past and still currently in some hospitals and practices, the parents are encouraged to dissociate themselves from the child, to forget him/her and to continue their lives without the child.

Modern day psychiatry teaches that human emotions, albeit feelings of joy, pain or anger, need to be experienced and accepted as part of each person's being

Our understanding of human emotion and behaviour thus does not coincide with the approach mentioned in the previous paragraph. It is these very painful feelings related to the mentally retarded child that need to be faced and not avoided. It is therefore the duty of the mental health professional to support the stressed couple. The professional must enhance the expression and clarify these feelings related to the mentally retarded child.

The family is a support system, the system which contributes to the emotional mastery of its members. The entire family needs to be mobilised to support each other in the experience of this pain related to the birth of the child. By virtue of her training the social worker is equipped to engage with the family. The medical professionals tell the parents the condition of their child. At the same time the social worker can be supporting the parents in their attempt to understand the tragedy. Very often the causes of the abnormality are unknown. This makes the interpretation and communication of the findings difficult for the professional. It is not difficult therefore, to understand why the family experience a traumatic period at such a time. The problem is a complex one, as has already been stated and there is a need for a team approach in order to solve it.

The birth and condition of the mentally retarded child needs to be explained to the siblings, as well as the parents. The family may need the social worker, to facilitate the communication amongst the family members. The family members need to share the feelings that they experience about the child. This is usually encouraged in a family interview. The social worker needs to facilitate the expression of feelings about and towards the child - an atmosphere of safety and trust is essential. Individual members usually need support in 
order to express negative and positive feelings. It is my experience that each individual family member experiences the tragedy in their own way and that they withdraw from each other to avoid talking about their pain. Communication subsequently breaks down and those who are under stress in fact become lonely and isolated from those they need most. In brief then, it is seen that there is a need for intervention right from the birth of the mentally retarded child - the essence of this interview is within a family context. The birth of a mentally retarded child is a great tragedy for the parents far more tragic than for the child itself. If indeed we follow the life of this unfortunate family, further problem areas could be high-lighted.

It is necessary at this stage to refer to the many cases where mental retardation is not detected at birth or soon thereafter. In such cases the milestones are delayed and the caretaker begins to wonder whether in fact there is something wrong with the child. Having undergone assessments - psychological, developmental and others, the parents may need to be told that their child is handicapped.

This is a tragic shock to the family and once again the family need clarity, support, guidance and understanding. It is often then that the parents approach a social agency in search of guidance and proper placement of their child. This is a crucial intervention and it is the social worker in contact with the family at that time who needs to be sensitive to the real needs - spoken and unspoken - of the family. In many cases it is not simply a search for institutional care. What they need is clarity about the facts, support in their stress and permission to feel whatever it is that they are experiencing, albeit hurt or anger towards the child. In other words the social worker needs to be aware of the current need of the family as well as to assist in the planning of the future for the child.

In the life of the mentally retarded child more often than not secondary emotional problems exist and manifest themselves in behavioural problems during childhood and particularly puberty. Sexuality for example becomes over-exaggerated and in fact becomes a problem when it need not necessarily be one. The textbook example is that of the scapegoat mentally retarded child who becomes reponsible for all marital and familial strife. The child is rejected and unwelcome and so masturbates excessively or attempts to fondle his sister's genitals in order to gain the attention he never receives otherwise. Or the child with the low frustration tolerance, as is sometimes the case in the mentally retarded or brain damaged child, becomes aggressive and violent and attempts to break his mother's most precious ornaments - again in an attempt to gain attention. What in fact is being said is that the needs of the mentally retarded child are synonymous with those of the normal child. These needs not being met, will also manifest themselves in "behaviour problems." These problems should be dealt with within the family system. The removal of the scapegoat, as requested by the family and often the professionals as well, will not alleviate the stress. Someone else in the system will merely become the scapegoat and the family structure will remain disintegrated.

It is this approach which is new and which high-lights the intervention of the social worker - this being her family orientation and treatment. Temporary admissions to centres, behaviour modification techniques, careful monitoring of chemotherapy, marital therapy and family therapy are the answers to these problems.

Temporary short term admissions (4 to 12 weeks) have proved to be desirable and successful. Such an admission enables the family to be relieved of the child for a short period whilst they are engaged in counselling. The aim of such an engagement in counselling the family is to enhance the family functioning and better equip the family to deal with the child in the future.

There are many crises in the life of the mentally retarded person and his family. The family's reactions to these are similar to the emotions experienced in chronic illness, namely that of lifelong stress and unresolved conflict about the future of the mentally retarded person. Problems continue to manifest themselves - during adolescence, at school-leaving age and during adulthood. Unlike the normal person experiencing similar crises, the mentally retarded person is far more dependent on his parents for the resolution of these crises. The parents of the mentally retarded person need to remain more actively involved in the decision making of their child.

Having looked at the need for a family approach to mental retardation and emphasised the role of the social worker, it is perhaps not inappropriate to mention also her aspect of the current situation: the placement back into the community, of those people who were institutionalised unnecessarily in the past. The social worker needs to know the community in order to utilise the facilities available, for example, accommodation. A communal house - attached to the Alexandra Care and Rehabilitation Centre, has successfully shown that adjustment to living in the community under supervision enhances further development and social functioning of the residents. Such carefully selected people need to experience a specialised social training program before discharge.

The social worker is a member of the team which runs such a program, using techniques such as role-play, sex education, psychodrama.

This placement in the community to live or even to work, is by no means easy. The families of these persons, having resigned themselves to the fact that their member is institutionalised for ever, have to change their attitude towards the person. They need to begin to see the person as an individual and no longer as a child. Very often these families need education, understanding, as well as support in accepting this new approach. Communication channels need to be opened between the mentally retarded person and his family. 
After-care services to the discharged residents are rendered on two levels. Firstly directly in weekly aftercare groups with the residents. Secondly indirect aftercare services are rendered through social work agencies - regular consultation and reporting ensures the adjustment of these residents in the community.

If the attitude of the family, the professionals and the community remains as it is at the moment, in fact the same as it was 20 years ago, namely that the removal and institutionalisation of the mentally retarded child is the only solution to the problem, then this new approach to mental retardation by a mere few professionals will be of no value to the mentally retarded per- son. In so doing the feelings of the retarded person are not being acknowledged, neither is his/her full potential for development being realised. The family in turn will continue to harbour unresolved feelings related to the mentally retarded person.

\section{REFERENCES:}

1. Caplan, Gerald and Killilea: Support Systems and Mutual Help: Multidisciplinary Explorations. New York, Grune and Stratton, 1976.

2. Gunzburg, H.C.: Advances in the Care of the Mentally Handicapped London, Bailliere Tindall, 1973.

3. McNab, Paul: Community Care of the Mentally Handicapped. Nursing Mirror, May 11 1978 .

4. Menolascino, Frank J.: Psychiatric Approaches to Mental Retardation. New York, Basic Books Inc., 1970.

5. Tizard, J.: Community Services for the Menfally Handicapped. London, Oxford University Press, 1964 